\title{
The influence of the testis on the fertilizing life of spermatozoa in the ligated vas deferens of the golden hamster
}

\author{
C. M. Lubicz-Nawrocki* and M. C. Chang \\ Worcester Foundation for Experimental Biology, Shrewsbury, Massachusetts 01545, U.S.A.
}

\begin{abstract}
Summary. Spermatozoa in the vas deferens of the hamster lose their fertilizing capacity 3 days after ligation of the initial part of the duct and after 2 days if the testes are removed at the time of ligation. Sham-ligation had no effect on the fertilizing life of vasal spermatozoa on the contralateral side even 3 days after bilateral castration. Unilateral castration for 3 days had no effect on the fertilizing capacity of spermatozoa from the ipsilateral unobstructed duct, whereas no eggs were fertilized by spermatozoa from the contralateral ligated duct associated with the remaining testis. Unlike testosterone, $5 \alpha$-dihydrotestosterone injected daily or implanted subcutaneously in Silastic tubes maintained normal fertilizing capacity for 2 days in castrates and for 3 days in intact males. Within each group, ligation had no effect on the level of fructose in the seminal vesicle on that side compared with the level in the gland on the other side.
\end{abstract}

\section{Introduction}

Observations on the storage capacity of the vas deferens in men and rams suggest that less than half the number of spermatozoa contained in a normal ejaculation are stored in the vas (Freund \& Davis, 1969; Tischner, 1972). After vasectomy in men, sexual abstinence or contraceptive precautions are advised for 6 weeks to several months and the success of the operation is judged clinically by the persistence of azoospermia following several ejaculations (Freund \& Davis, 1969). There is, however, no information for men or laboratory animals on the fertilizing life of spermatozoa in the vas deferens. It is feasible that, compared with the long fertilizing life of 2-4 weeks in the cauda epididymidis in different species (see Orgebin-Crist, Danzo \& Davies, 1975), survival of vasal spermatozoa might be relatively short because of their chronological age and the possibility that less favourable conditions exist there for sperm survival (Jones, 1974). Although circulating testicular androgens are essential for the maintenance of fertilizing capacity of spermatozoa in the cauda epididymidis (Lubicz-Nawrocki \& Glover, 1970, 1973; Dyson \& Orgebin-Crist, 1973; Orgebin-Crist et al., 1975), it is not known whether the survival of vasal spermatozoa is influenced mainly by circulating androgen or by $5 \alpha-$ dihydrotestosterone which is present in high concentrations in the lumen of the cauda epididymidis (Ganjam \& Amann, 1973; Back, 1975) and also perhaps in the luminal fluid of the vas deferens. Evidence supporting androgen transport through the duct was presented by Skinner \& Rowson (1968) who postulated that growth of the ampulla was stimulated by luminal passage of androgens through the vas deferens. The present study was undertaken to test the possibility that luminal passage of androgen might also be important for maintaining the fertilizing capacity of vasal spermatozoa.

\section{Materials and Methods}

Male and female hamsters (125-135 g) were maintained under controlled conditions of temperature and light.

To determine the fertilizing life of spermatozoa in the vas deferens, the inflow of fresh spermatozoa was blocked by ligating the left duct at its junction with the cauda epididymidis (Text-fig. 1a) with two braided, sterilized silk sutures (size 5/0, Ethicon), placed approximately $2 \mathrm{~mm}$ apart with minimal

\footnotetext{
* Present address: Instituto de Biologia y Medicina Experimental Laboratorio de Esteroides, Obligado 2490, 1428 Buenos Aires, Cap. Fed., Argentina.
} 
disturbance to the vasculature; on the sham-operated right side, loose ligatures were tied without constricting the duct. Groups of 6 males were killed 1,2 and 3 days after surgery and the left and right vas deferens from each male was flushed with 0.2 and $0.8 \mathrm{ml}$ sterilized Hank's solution at room temperature $\left(24^{\circ} \mathrm{C}\right)$, respectively, by inserting a 25 -gauge needle attached to a tuberculin syringe into the duct. Sperm suspensions from the control sides were diluted so that comparable numbers of spermatozoa could be artificially inseminated because sperm numbers gradually decrease in the hamster vas deferens after ligation (C. M. Lubicz-Nawrocki, unpublished observations).

To test the fertilizing capacity of spermatozoa, a $0.15 \mathrm{ml}$ volume of the suspension of spermatozoa from the control and ligated vas deferens of each male was injected, within 5 min of removal from the vas, into the right and left uterine horns, respectively, of an oestrous female hamster. Before insemination, a loose ligature was tied around the cervical ends of each uterine horn and then tightened after injection of the sperm suspension to prevent transuterine migration of spermatozoa (LubiczNawrocki, 1970). Eggs were flushed from the oviducts approximately $40 \mathrm{~h}$ after insemination, mounted in toto (Chang, 1952) and examined with a phase-contrast microscope for evidence of fertilization, i.e. the presence of a spermatozoon in the vitellus of a cleaved egg. Fertilizing capacity of spermatozoa was estimated in terms of fertilization rate as the percentage of fertilized eggs recovered from the inseminated females.

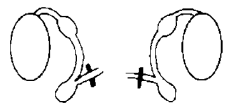

(a)

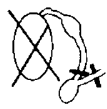

(b)

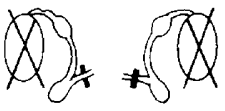

(c)

Text-fig. 1. Schematic representation of the surgical procedures used. (a) Unilateral ligation of the vas deferens compared with shan-ligation; (b) unilateral ligation of the vas deferens compared with shamligation and removal of the ipsilateral testis after bilateral ligation of the corpus epididymidis; (c) unilateral ligation of the vas deferens compared with sham-ligation after bilateral castration.

To test the influence of the testes on the fertilizing life of vasal spermatozoa, 12 males were bilaterally castrated immediately after ligation of the duct (Text-fig. 1c). Six males were killed after 2 days and the remainder on the 3 rd day to test the fertilizing capacity of the spermatozoa.

Experiments were then undertaken to ascertain whether the effects of ligation of the vas deferens act by interrupting the flow of material from the cauda epididymidis and to examine the importance of circulating androgens in this respect. In the first test (Text-fig. 1b), 6 males were unilaterally castrated (right side) and the flow of spermatozoa and fluid into the ipsilateral cauda epididymidis was prevented by ligating the distal end of the corpus epididymidis (Lubicz-Nawrocki \& Glover, 1973), and a loose ligature was placed round the vas deferens as described above. The corpus epididymidis and the vas deferens were ligated on the left side where the testis was still present. The animals were killed after 3 days to test the fertilizing capacity of the vasal spermatozoa.

In the next experiment the vas deferens was unilaterally ligated in groups of intact and castrated males which were then treated with testosterone or $5 a$-dihydrotestosterone for 3 days (intact males) and 2 or 3 days (castrated males). Only single concentrations of $150 \mu \mathrm{g}$ testosterone and $100 \mu \mathrm{g} 5 \alpha-$ dihydrotestosterone/day were injected because half these daily doses are sufficient to maintain normal fertilizing ability of spermatozoa in the cauda epididymidis of the castrated hamster (LubiczNawrocki, 1973). The androgens were injected subcutaneously in sesame oil once daily or administered in Silastic tubes (polydimethylsiloxane; PDS) (see Table 3). The PDS implants were prepared from Silastic medical-grade tubing (Dow Corning Corp., Midland, Michigan; No. 602-231: 0.75 cm long, $0 \cdot 13 \mathrm{~cm}$ i.d., $0 \cdot 17 \mathrm{~cm}$ o.d.), filled with $4 \cdot 5-5 \mathrm{mg}$ dry testosterone or $5 \alpha$-dihydrotestosterone (Sigma Chemical Corp.) and closed with medical adhesive (Type A, No. 891, Dow Corning Corp.). Before implantation, the PDS tubes were sterilized in $70 \%$ ethanol for $15 \mathrm{~min}$, dried and then implanted subcutaneously (two per male) 2-3 days before further treatment of the animals (Table 3). 
Table 1. The fertilizing capacity of the spermatozoa from the vas deferens of the hamster after different periods of ligation

\begin{tabular}{|c|c|c|c|c|c|c|}
\hline $\begin{array}{c}\text { Days } \\
\text { after } \\
\text { operation }\end{array}$ & Operation & $\begin{array}{c}\text { No. of } \\
\text { females } \\
\text { inseminated* }\end{array}$ & $\begin{array}{c}\text { No. of } \\
\text { sperm./ } \\
\text { uterine } \\
\text { horn }\left(\times 10^{6}\right)\end{array}$ & $\begin{array}{l}\text { Total no. } \\
\text { of eggs } \\
\text { recovered } \dagger\end{array}$ & $\begin{array}{c}\text { Fertilization } \\
\text { rate } \neq\end{array}$ & $\begin{array}{c}\text { Seminal } \\
\text { vesicle } \\
\text { fructose } \\
\text { (mg/g dry wt) }\end{array}$ \\
\hline \multirow[t]{2}{*}{1} & Ligation & \multirow[t]{2}{*}{6} & $1.87 \pm 0.4$ & 33 & $100(0)$ & $2.41 \pm 0.4$ \\
\hline & Sham-ligation & & $1 \cdot 77 \pm 0 \cdot 2$ & 28 & 100 & $2.96 \pm 0.5$ \\
\hline \multirow{2}{*}{2} & Ligation & \multirow{2}{*}{6} & $1.92 \pm 0.6$ & 32 & $71 \cdot 8(2)$ & $3.01 \pm 0.22$ \\
\hline & Sham-ligation & & $2.08 \pm 0.4$ & 27 & 100 & $3 \cdot 22 \pm 0.3$ \\
\hline \multirow{2}{*}{3} & Ligation & \multirow{2}{*}{6} & $1.9 \pm 0.6$ & 24 & $0(6)$ & $2 \cdot 18 \pm 0 \cdot 44$ \\
\hline & Sham-ligation & & $2.03 \pm 0.32$ & 32 & 100 & $2.43 \pm 0.67$ \\
\hline
\end{tabular}

Values are mean \pm s.e.m.

* One female/male; spermatozoa from the ligated and sham-ligated vas deferens injected into the left and right uterine horns, respectively.

$\dagger$ At $48 \mathrm{~h}$ after insemination.

¥ As the $\%$ of eggs recovered; no. of horns without fertilized eggs in parentheses.

Table 2. The effects (mean \pm s.e.m.) of bilateral castration and ligation of the corpus epididymidis of the hamster on the fertilizing capacity of vasal spermatozoa after ligation of the vas deferens

\begin{tabular}{|c|c|c|c|c|c|c|c|}
\hline $\begin{array}{c}\text { Days } \\
\text { after } \\
\text { operation }\end{array}$ & Ope & ration & $\begin{array}{c}\text { No. of } \\
\text { females } \\
\text { inseminated }\end{array}$ & $\begin{array}{c}\text { No. of } \\
\text { sperm./ } \\
\text { uterine } \\
\text { horn } \\
\left(\times 10^{6}\right)\end{array}$ & $\begin{array}{l}\text { No. of } \\
\text { eggs } \\
\text { recovered } \dagger\end{array}$ & $\begin{array}{l}\text { Fertil- } \\
\text { ization } \\
\text { rate }\end{array}$ & $\begin{array}{c}\text { Seminal } \\
\text { vesicle } \\
\text { fructose } \\
\text { (mg/g dry wt) }\end{array}$ \\
\hline \multirow[t]{2}{*}{2} & \multirow{2}{*}{$\begin{array}{l}\text { Bitateral } \\
\text { castration }\end{array}$} & $\begin{array}{l}\text { Ligation of } \\
\text { vas deferens }\end{array}$ & \multirow[t]{2}{*}{6} & $1.74 \pm 0.2$ & 46 & 0 & $3.52 \pm 0.48$ \\
\hline & & Sham-ligation & & $1.89 \pm 0.3$ & 30 & 100 & $3 \cdot 12 \pm 0.56$ \\
\hline \multirow[t]{2}{*}{3} & \multirow{2}{*}{$\begin{array}{l}\text { Bilateral } \\
\text { castration }\end{array}$} & $\begin{array}{l}\text { Ligation of } \\
\text { vas deferens }\end{array}$ & \multirow[t]{2}{*}{6} & $1.9 \pm 0.6$ & 30 & 0 & $2 \cdot 94 \pm 0 \cdot 1$ \\
\hline & & Sham-ligation & & $2.01 \pm 0.5$ & 30 & 100 & $2.68 \pm 0.2$ \\
\hline \multirow[t]{2}{*}{3} & $\begin{array}{l}\text { Ligation of } \\
\text { corpus } \\
\text { epididymidis }\end{array}$ & $\begin{array}{l}\text { Ligation of } \\
\text { vas deferens }\end{array}$ & \multirow{2}{*}{6} & \multirow{2}{*}{$\begin{array}{l}2.2 \pm 0.4 \\
2.11 \pm 0.55\end{array}$} & 27 & 0 & $4 \cdot 24 \pm 0.49$ \\
\hline & $\begin{array}{l}\text { Castration } \\
\text { and ligation } \\
\text { of corpus } \\
\text { epididymidis }\end{array}$ & Sham-ligation & & & 40 & 100 & $3.44 \pm 0.74$ \\
\hline
\end{tabular}

* One male/female; see Table 1.

$\dagger$ At $\mathbf{4 8} \mathrm{h}$ after insemination.

$\ddagger$ As the $\%$ of eggs recovered. 
Finally, the fertilizing capacity of spermatozoa from different regions of the duct was determined to see whether the effects of ligation are mainly exerted on spermatozoa in the initial part of the vas deferens. Three untreated males were killed and spermatozoa were separately flushed from the initial and distal one-third of each vas deferens; $0.51 \mathrm{ml}$ of each sperm suspension was inseminated into the left and right uterine horns, respectively, of one oestrous female as described above.

In each male, the concentration of fructose in each lobe of the seminal vesicles was determined to ascertain if short-term ligation of the vas deferens decreased the level of this androgen-dependent sugar, as reported after prolonged vasectomy in rats (Pierrepoint, Davies, Lewis \& Moffat, 1975). Each lobe was blotted on filter paper to remove the secretion and stored at $-20^{\circ} \mathrm{C}$. Fructose was assayed in approximately $90 \%$ of each lobe by a slight modification (Lubicz-Nawrocki \& Glover, 1973) of the method originally described by Lindner \& Mann (1960). The remainder of the lobe was dried to constant weight at $150^{\circ} \mathrm{C}$ to determine the percentage of dry matter.

Table 3. The fertilizing capacity of vasal spermatozoa from the ligated vas deferens of intact and bilaterally castrated hamsters treated with testosterone $(T, 150 \mu \mathrm{g} / \mathrm{day})$ or $5 \alpha$-dihydrotestosterone $(5 \alpha-\mathrm{DHT}, 100 \mu \mathrm{g} /$ day $)$

\begin{tabular}{|c|c|c|c|c|c|c|c|c|}
\hline $\begin{array}{c}\text { Days } \\
\text { after } \\
\text { operation }\end{array}$ & Op & ration & Hormone & $\begin{array}{l}\text { No. of } \\
\text { females in- } \\
\text { seminated* }\end{array}$ & $\begin{array}{c}\text { No. of } \\
\text { sperm./ } \\
\text { uterine } \\
\text { horn } \\
\left(\times 10^{6}\right)\end{array}$ & $\begin{array}{l}\text { No. of } \\
\text { eggs } \\
\text { recovered } \uparrow\end{array}$ & $\begin{array}{l}\text { Fertil- } \\
\text { ization } \\
\text { rate } \neq\end{array}$ & $\begin{array}{l}\text { Seminal } \\
\text { vesicle } \\
\text { fructose } \\
\text { (mg/g } \\
\text { dry wt) }\end{array}$ \\
\hline 2 & Castration & $\begin{array}{l}\text { Ligation of } \\
\text { vas deferens } \\
\text { Sham-ligation }\end{array}$ & $\mathbf{T}$ & 6 & $\begin{array}{l}1.9 \pm 0.6 \\
2.04 \pm 0.3\end{array}$ & $\begin{array}{l}28 \\
30\end{array}$ & $\begin{array}{l}21 \cdot 4(4) \\
100\end{array}$ & $\begin{array}{l}3.54 \pm 0.49 \\
3.52 \pm 0.2\end{array}$ \\
\hline 3 & Castration & $\begin{array}{l}\text { Ligation of } \\
\text { vas deferens } \\
\text { Sham-ligation. }\end{array}$ & $\mathbf{T}$ & 6 & $\begin{array}{l}1.8 \pm 0.1 \\
1.9 \pm 0.5\end{array}$ & $\begin{array}{l}37 \\
42\end{array}$ & $\begin{array}{l}2 \cdot 7(5) \\
100\end{array}$ & $\begin{array}{l}3.61 \pm 0.3 \\
3.68 \pm 0.31\end{array}$ \\
\hline 2 & Castration & $\begin{array}{l}\text { Ligation of } \\
\text { vas deferens } \\
\text { Sham-ligation }\end{array}$ & $5 \alpha-\mathrm{DHT}$ & 8 & $\begin{array}{l}1 \cdot 72 \pm 0 \cdot 3 \\
1 \cdot 71 \pm 0 \cdot 1\end{array}$ & $\begin{array}{l}30 \\
42\end{array}$ & $\begin{array}{l}100(0) \\
100\end{array}$ & $\begin{array}{r}3.3 \pm 0.5 \\
4.17 \pm 0.4\end{array}$ \\
\hline 3 & Castration & $\begin{array}{l}\text { Ligation of } \\
\text { vas deferens } \\
\text { Sham-ligation }\end{array}$ & $5 \alpha-\mathrm{DHT}$ & 8 & $\begin{array}{l}1.84 \pm 0.2 \\
1.81 \pm 0.4\end{array}$ & $\begin{array}{l}32 \\
39\end{array}$ & $\begin{array}{l}50(4) \\
100\end{array}$ & $\begin{array}{r}3.24 \pm 0.4 \\
3.9 \pm 0.2\end{array}$ \\
\hline 3 & Intact & $\begin{array}{l}\text { Ligation of } \\
\text { vas deferens } \\
\text { Sham-ligation }\end{array}$ & $\mathbf{T}$ & 6 & $\begin{array}{l}1.94 \pm 0.3 \\
2.04 \pm 0.4\end{array}$ & $\begin{array}{l}32 \\
35\end{array}$ & $\begin{array}{l}0(6) \\
100\end{array}$ & $\begin{array}{l}3.47 \pm 0.4 \\
3.97 \pm 0.1\end{array}$ \\
\hline 3 & Intact & $\begin{array}{l}\text { Ligation } \\
\text { vas deferens } \\
\text { Sham-ligation }\end{array}$ & $5 \alpha-\mathrm{DHT}$ & 8 & $\begin{array}{l}1.74 \pm 0.3 \\
2.14 \pm 0.3\end{array}$ & $\begin{array}{l}42 \\
37\end{array}$ & $\begin{array}{l}45(4) \\
100\end{array}$ & $\begin{array}{l}2 \cdot 64 \pm 0 \cdot 1 \\
3 \cdot 37 \pm 0 \cdot 4\end{array}$ \\
\hline
\end{tabular}

Values are mean \pm s.e.m.

* One male/female; see Table 1 .

$\dagger$ At $48 \mathrm{~h}$ after insemination.

$\ddagger$ As the \% of eggs recovered; no. of horns without fertilized eggs in parentheses.

\section{Results}

Table 1 shows that loose ligatures of the vas deferens had no effect on the fertilizing capacity of vasal spermatozoa whereas most of the spermatozoa on the ligated side were immotile and had lost their fertilizing capacity after 3 days. 
Table 2 shows that bilateral castration combined with ligation of the vas deferens caused an even more rapid loss of fertilizing capacity because no eggs were fertilized 2 days after surgery, although spermatozoa on the sham-operated side retained normal fertilizing capacity for at least 3 days. The combined effect of ligation of the vas deferens, removal of the contralateral testis and ligation of the corpus epididymidis on the fertilizing capacity of vasal spermatozoa (Table 2) was the same as when the testes and epididymides were left intact (Table 1): vasal spermatozoa in the unligated vas deferens from each male showed normal fertilizing capacity after 3 days even though the ipsilateral testis was removed, but none of the eggs was fertilized by spermatozoa from the ligated duct where the corresponding testis remained in situ (Table 2).

The fertilization rates after androgen treatment of bilaterally castrated or intact males, showed that daily injections of $150 \mu \mathrm{g}$ testosterone did not significantly prolong the fertilizing life of spermatozoa after ligation of the vas deferens. However, $100 \mu \mathrm{g} 5 \alpha$-dihydrotestosterone/day maintained normal fertilizing capacity of spermatozoa in the vas deferens for 2 days in each castrated male and for 3 days in 4 of 8 castrated males. A dose of $100 \mu \mathrm{g} 5 \alpha$-dihydrotestosterone maintained normal fertilizing capacity in 3 of 8 intact males (Table 3 ).

Table 4 shows that continuous release of testosterone from Silastic tubes implanted subcutaneously in castrated and intact males also failed to prevent loss of fertilizing capacity of vasal spermatozoa after ligation of the deferent duct. The fertilization rates after continuous treatment of castrated males with $5 \alpha$-dihydrotestosterone, however, were similar (Table 4) to those obtained after intermittent injection of the androgen into castrated and intact males (Table 3 ).

Table 4. The fertilizing capacity of vasal spermatozoa from intact and bilaterally castrated hamsters subcutaneously implanted with a Silastic tube containing $4.5-5 \mathrm{mg}$ testosterone $(\mathrm{T})$ or $5 \alpha$-dihydrotestosterone (5 $\alpha$-DHT)

\begin{tabular}{|c|c|c|c|c|c|c|c|c|}
\hline $\begin{array}{c}\text { Days } \\
\text { after } \\
\text { operation }\end{array}$ & Op & eration & Hormone & $\begin{array}{c}\text { No. of } \\
\text { females in- } \\
\text { seminated* }\end{array}$ & $\begin{array}{c}\text { No. of } \\
\text { sperm./ } \\
\text { uterine } \\
\text { horn } \\
\left(\times 10^{6}\right)\end{array}$ & $\begin{array}{l}\text { Total no. } \\
\text { of eggs } \\
\text { recoveredt }\end{array}$ & $\begin{array}{c}\text { Fertil- } \\
\text { ization } \\
\text { ratef }\end{array}$ & $\begin{array}{c}\text { Seminal } \\
\text { vesicle } \\
\text { fructose } \\
(\mathrm{mg} / \mathrm{g} \\
\text { dry } w \mathrm{t})\end{array}$ \\
\hline \multirow[b]{2}{*}{2} & \multirow{2}{*}{ Castration } & Ligation & \multirow{2}{*}{$\mathbf{T}$} & \multirow[b]{2}{*}{6} & $2 \cdot 2 \pm 0 \cdot 3$ & 32 & $10(4)$ & $3.82 \pm 0.33$ \\
\hline & & Sham-ligation & & & $1.86 \pm 0.2$ & 30 & 100 & $3.86 \pm 0.3$ \\
\hline \multirow[b]{2}{*}{3} & \multirow[b]{2}{*}{ Castration } & Ligation & \multirow[b]{2}{*}{$\mathrm{T}$} & \multirow[b]{2}{*}{6} & $2.4 \pm 0.2$ & 31 & $0(6)$ & $4.51 \pm 0.5$ \\
\hline & & Sham-ligation & & & $1.9 \pm 0.3$ & 27 & 100 & $4.29 \pm 0.49$ \\
\hline \multirow[b]{2}{*}{2} & \multirow[b]{2}{*}{ Castration } & Ligation & \multirow[b]{2}{*}{$5 \alpha-\mathrm{DHT}$} & \multirow[b]{2}{*}{6} & $2 \cdot 1 \pm 0 \cdot 3$ & 28 & $100(0)$ & $4 \cdot 33 \pm 0 \cdot 3$ \\
\hline & & Sham-ligation & & & $1.78 \pm 0.5$ & 32 & 100 & $4 \cdot 14 \pm 0.81$ \\
\hline \multirow{2}{*}{3} & \multirow{2}{*}{ Castration } & Ligation & \multirow{2}{*}{$5 \alpha-\mathrm{DHT}$} & \multirow{2}{*}{6} & $1.9 \pm 0.2$ & 34 & $40(3)$ & $4.59 \pm 0.5$ \\
\hline & & Sham-ligation & & & $2 \cdot 1 \pm 0 \cdot 3$ & 29 & 100 & $4 \cdot 26 \pm 0.44$ \\
\hline \multirow[b]{2}{*}{3} & \multirow[b]{2}{*}{ Intact } & Ligation & \multirow[b]{2}{*}{$\mathrm{T}$} & \multirow[b]{2}{*}{6} & $1.7 \pm 0.4$ & 36 & $0(6)$ & $4.43 \pm 0.5$ \\
\hline & & & & & $1.8 \pm 0.2$ & 40 & 100 & $3.61 \pm 0.3$ \\
\hline \multirow{2}{*}{3} & \multirow{2}{*}{ Intact } & Ligation & \multirow{2}{*}{$5 a-\mathrm{DHT}$} & \multirow{2}{*}{9} & $1.9 \pm 0.3$ & 62 & $90 \cdot 2(0)$ & $4.59 \pm 0.51$ \\
\hline & & Sham-ligation & & & $1.66 \pm 0.2$ & 38 & 100 & $4.76 \pm 0.9$ \\
\hline
\end{tabular}

Values are mean \pm s.e.m.

* One male/female; see Table I.

+ At $48 \mathrm{~h}$ after insemination.

$\ddagger$ As the $\%$ of eggs recovered; no. of horns without fertilized eggs in parentheses. 
Spermatozoa from the initial part of the unligated vas deferens in each of the 3 males showed the expected normal degree of fertilizing capacity $(100 \%)$ whereas only 1 of 5,2 of 8 and 2 of 7 eggs (a mean fertilization rate of $22.9 \%$ ) were fertilized by spermatozoa from the urethral end of the duct.

Within each group, ligation of the vas deferens had no effect on the level of vesicular fructose compared with that on the intact side. However, fructose levels were higher in animals receiving androgen treatment than in those which did not.

\section{Discussion}

The results show that the fertilizing life of vasal spermatozoa is only 2 or 3 days after ligation of the vas deferens if the testes are left intact but less than 2 days following bilateral castration. Sham ligation and ligation of the corpus epididymidis, however, had no effect even after removal of the ipsilateral testis or after bilateral castration. The retention of fertilizing capacity by spermatozoa in the unligated vas deferens for at least 3 days after bilateral castration is consistent with previous findings that mature spermatozoa in the cauda epididymidis retained their fertilizing capacity for several days in the absence of circulating testicular androgen (Lubicz-Nawrocki \& Glover, 1973). Therefore, since vasectomy does not seriously impair the capacity of the cauda epididymidis to maintain a stable milieu in the lumen of the duct (Jones, 1974), ligation of the proximal part of the vas deferens must induce changes in the more distal regions of the excurrent duct resulting in loss of fertilizing capacity and death of the spermatozoa. At present, there is no information on the period of sperm residence in the cauda epididymidis of any species but isotope labelling of the sperm nucleus in several species has shown that sperm transit through the epididymis requires only 1-2 weeks (see Bedford, 1975). Since spermatozoa from the hamster cauda epididymidis can survive for 12 days (Lubicz-Nawrocki \& Glover, 1973) and their passage from the caput to the cauda epididymidis only takes a few days (Mason \& Shaver, 1952; Lubicz-Nawrocki \& Chang, 1974, 1975), a fertilizing life of 1-2 weeks rather than 2-3 days might be expected for vasal spermatozoa. The present demonstration of the very large difference in the fertilizing capacity of vasal spermatozoa from the proximal and distal regions of the duct suggest that the short fertilizing life of spermatozoa might be due to the effects of ageing during epididymal transit.

It is difficult to explain why testosterone was not effective in prolonging the fertilizing life of vasal spermatozoa following castration, especially because autoradiographic and biochemical evidence (Appelgren, 1969; Hansson \& Tveter, 1971) indicates uptake and binding of testosterone in the vas deferens of the mouse and rat. The present study suggests that circulating testosterone is much less important for sperm survival in the hamster vas deferens than in the cauda epididymidis (LubiczNawrocki \& Glover, 1973) where testosterone is almost equipotent with $5 \alpha$-dihydrotestosterone for the maintenance of fertilizing capacity (Lubicz-Nawrocki, 1973). It is not clear why only 5 $\alpha$-dihydrotestosterone prolonged the fertilizing life of vasal spermatozoa in castrated hamsters; one possibility might be a poor ability to convert testosterone to $5 \alpha$-dihydrotestosterone as shown in the rat (Rajalakshmi \& Prasad, 1976). Although the present study suggests a local role for 5 $\alpha$-dihydrotestosterone in sperm survival, it is not possible to decide whether the exogenous $5 \alpha$-dihydrotestosterone acted through the epithelium or more directly by entering the lumen of the deferent duct. High levels of $5 \alpha$-dihydrotestosterone have been detected in the lumen of the cauda epididymidis of bulls (Ganjam \& Amann, 1973) and rats (Back, 1975) and the level of 5 $\alpha$-dihydrotestosterone in ejaculates of men decreases markedly after vasectomy (Purvis, Saksena, Cekan, Diczfalusy \& Giner, 1976). In view of this evidence and the efficacy with which $5 \alpha$-dihydrotestosterone prolonged the survival of vasal spermatozoa in castrated hamsters, it is possible that an uninterrupted flow of this androgen and possibly other "sperm-survival promoting factors" (Morita \& Chang, 1970; Morton \& Chang, 1973) is necessary to prevent premature loss of fertilizing capacity of spermatozoa after their passage into the vas deferens.

This study was supported by a grant from the Ford Foundation and a grant (HD 03472) from the NICHD, U.S. Public Health Service. We thank Mrs E. Senior for typing assistance. 


\section{References}

Appelgren, L.E. (1969) The distribution of labelled testosterone in mice. Acta endocr., Copenh. 62, 505512.

BACK, D.J. (1975) The presence of metabolites of ${ }^{3} \mathrm{H}-$ testosterone in the lumen of the epididymis of the rat. Steroids 25, 413-420.

BEDFord, J.M. (1975) Maturation, transport, and the fate of spermatozoa in the epididymis. In Handbook of Physiology, Section 7, Vol. 5, pp. 303-317. Eds D. W. Hamilton \& R. O. Greep. American Physiological Society, Washington, D.C.

Chang, M.C. (1952) Fertilizability of rabbit ova and effects of temperature in vitro on their subsequent fertilization and activation in vivo. J. exp. Zool. 121, $351-381$.

Dyson, A.L.M.B. \& Orgebin-Crist, M.-C. (1973) Effect of hypophysectomy, castration and androgen replacement upon the fertilizing ability of rat epididymal spermatozoa. Endocrinology 93, 391-402

Freund, M. Davis, J.E. (1969) Disappearance rate of spermatozoa from the ejaculate following vasectomy. Fert. Steril. 20, 163-170.

Ganjam, V.K. \& AMANN, R.P. (1973) Testosterone and dihydrotestosterone concentrations in the fluid milieu of spermatozoa in the reproductive tract of the bull. Acta endocr., Copenh. 74, 186-200.

Hansson, V. \& TVeter, K.J. (1971) Uptake and binding in vivo of ${ }^{3} \mathrm{H}$ labelled androgen in the rat epididymis and ductus deferens. Acta endocr., Copenh. 66, 745755.

JoNES, R. (1974) Epididymal function in the vasectomized rabbit. J. Reprod. Fert. 36, 199-202.

LINDNER, H.R. \& MANN, T. (1960) Relationship between the content of androgenic steroids in the testes and the secretory activity of the seminal vesicles in the bull. J. Endocr. 21, 341-360.

LubiCZ-NAWrocki, C.M. (1970) Transuterine migration of spermatozoa in the golden hamster (Mesocricetus auratus). J. Reprod. Fert. 23, 197-199.

Lubicz-Nawrocki, C.M. (1973) The effect of metabolites of testosterone on the viability of hamster epididymal spermatozoa. J. Endocr. 58, 193-198.

Lubicz-Nawrocki, C.M. \& Chang, M.C. (1974) The onset and duration of infertility in hamsters treated with $\alpha$-chlorohydrin. J. Reprod. Fert. 39, 291-295.

Lubicz-Nawrocki, C.M. \& Chang, M.C. (1975) Effect of 4-chloromethyl-2-methyl-2-pentyl-1,3dioxolane (AY-22,352) on the fertilizing ability of hamster epididymal spermatozoa.J. Reprod. Fert. 43, 281-286.

Lubicz-NaWrocki, C.M. \& Glover, T.D. (1970) Effects of gonadectomy and testosterone replacement on the viability of epididymal spermatozoa in the golden hamster (Mesocricetus auratus). J. Endocr. 48, xxii-xxiii.

Lubicz-Nawrocki, C.M. \& Glover, T.D. (1973) The influence of the testis on the survival of spermatozoa in the epididymis of the golden hamster (Mesocricetus auratus). J. Reprod. Fert. 34, 315-329.

Mason, K.E. \& Shaver, S.L. (1952) Some functions of the caput epididymidis. Ann. N.Y. Acad. Sci.55, 585593.

Morita, Z. \& Chang, M.C. (1970) The motility and aerobic metabolism of spermatozoa in laboratory animals with special reference to the effects of cold shock and the importance of calcium for the motility of hamster spermatozoa. Biol. Reprod. 3, 169-179.

Morton, B. \& Chang, T.S.K. (1973) The effect of fluid from the cauda epididymidis, serum components and caffeine upon the survival of diluted epididymal hamster spermatozoa. J. Reprod. Fert. 35, 255-263.

Orgebin-Crist, M.-C., DANzo, B.J. \& Davies, J. (1975) Endocrine control of the development and maintenance of sperm fertilizing ability in the epididymis. In Handbook of Physiology, Section 7, Vol. 5, pp. 319338. Eds D. W. Hamilton \& R. O. Greep. American Physiological Society, Washington, D.C.

Pierrepoint, C.G., Davies, P., Lewis, M.H. \& Moffat, D.B. (1975) Examination of the hypothesis that a direct control system exists for the prostate and seminal vesicles. J. Reprod. Fert. 44, 395-409.

Purvis, K., Saksena, S.K., Cekan, Z., Diczfalusy, E. \& GINER, J. (1976) Endocrine effects of vasectomy. Clin. Endocr. 5, 263-272.

Rajalaks̈hmi, M. \& Prasad, M.R.N. (1976) Metabolism of testosterone by the epididymis and ventral prostate of rat and its inhibition by cyproterone acetate. Steroids 28, 143-157.

Skinner, J.D. \& Rowson, L.E.A. (1968) Effects of testosterone injected unilaterally down the vas deferens on the accessory glands of the ram.J. Endocr. 42, 355-356.

TISCHNER, M. (1972) The role of the vasa deferentia and the urethra in the transport of semen in rams. Acta agrar. silvestria, Series Zootechnica 12, 77-113. 